\title{
MDK Gene
}

National Cancer Institute

\section{Source}

National Cancer Institute. MDK Gene. NCI Thesaurus. Code C24589.

This gene is involved in nervous tissue development. It plays a role in neuronal differentiation, growth, regeneration and survival. 